\title{
Pro-Epidermal Growth Factor
}

National Cancer Institute

\section{Source}

National Cancer Institute. Pro-Epidermal Growth Factor. NCI Thesaurus. Code 1118403.

Pro-epidermal growth factor (1207 aa, $\sim 134 \mathrm{kDa}$ ) is encoded by the human EGF gene.

This protein plays a role in the modulation of cell proliferation and differentiation. 